\title{
The Egyptian Cemeteries as a Tourist Destination
}

\section{بسمة سليم1}

\section{basmaselim81@gmail.com}

\section{Abstract:}

Tourism is the fastest growing phenomenon, not only economically, but also all its aspects changing rapidly in a constant attempt to introduce new experiences, create new incentives and reach new markets.This endeavor results in new tourism programs that were a few years ago unimaginable. These new ideas are in fact a response to the growing demand from customers fornew feelings and knowledge in the search for strange, unusual and unique memories. One of those ideas is the cemeteries tourism.

This paper aims to re-establish the urban cemeteries in Egypt among the tourist supplies and to present their values as cultural tourism products that can enrich visitors' experiences.Contemporary tourist literature classifies this type of tourism asthe dark tourism only in most cases; thus, the potentials of the cemeteries as cultural products are being neglected.This paper corrects that by saying that thecemeteries tourism offers a fascinating cultural show for tourists, where both natural and cultural activities are

1- باحث دكتوراه بكلية السياحة والفنادق - جامعة حلوان 
presented and, therefore, it can be legally placed in heritage and cultural tourism.

This paper deals with different types of cemetery visits in Egypt, and the City of the Dead or the Mamluks cemetery is studied as a case study with the presentation of similar global models and practices.

Key words: Cemeteries tourism, dark tourism, cultural heritage, and the City of the Dead, tourism resource, tourism attraction.

The dictionary definescemetery as "an area of ground in which dead bodies are buried". ${ }^{2}$ The cemetery is a built-up geographical area, which performs the function of burial in accordance with various legal principles relating to burial rites and different traditions to commemorate those who died. ${ }^{3}$ If we assume that the historical cemetery is part of the graphical geographical area and the tourists' point of interest (i.e. the space in which tourism is located), it can be assumed to be part of the tourist space as well.

Where the spatial differences, climate and physical and human characteristics of a particular area are closely related to tourism science as tourism activity takes place within the geographical boundaries.So, the cemetery area, just like the tourist space, is subject to change.Certainly, the cemetery can

${ }^{2}$ Cambridge Dictionary, accessed March 2, 2019, https://dictionary.cambridge.org/dictionary/english/cemetery. ${ }^{3}$ SlwojTanas, "The Cemetery as a Part of the Geography of Tourism" Institute of Urban Geography and Tourism Studies, (University of Lodzki, 2004): 73. 
be a place for 'exploration' and 'penetration', and when it is part of urban space it is subject to 'urbanization'. 4

Contemporary tourism literature classifies this type of tourism through a number of terms. For example:

Seaton (1996) used the term "thanatourism", which he defined as "travel to a location wholly, or partially, motivated by the desire for actual or symbolic encounters with death" "According to him, "thanatopsis" served the purpose of reducing the fear of death and making people ready for it where death was seen as a normal part of life. ${ }^{6}$

However, Rojek used the concept of "black spot" to refer to two types of places related to death. On the one hand, death sites such as cemeteries where celebrities or memorials are buried for the memory of privileged people. On the other hand, places referred to as "disaster sites and prominent death sites".These sites included places such as concentration camps, killing fields of Cambodia and the place where Kurt Cobain committed suicide. ${ }^{7}$

Lennon and Foley introduced the term "Dark Tourism" and defined it as "the phenomenon which encompasses the

${ }^{4}$ Tanas, "The Cemetery." 81.

${ }^{5}$ A.V.Seaton, "Guided by the Dark: From Thanatopsis to

Thanatourism", International Journal of Heritage Studies, 2 (4),

(1996):240.

${ }^{6}$ Seaton, "Guided," 239

${ }^{7}$ Chris Rojek and JohnUrry, Touring Cultures: Transformations of Travel and Theory(Taylor \& Francis e-Library,2003), 62, http://www.academia.edu/823938/Touring_Cultures_by_Urry_and_Roj ek_book_ 
presentation and consumption (by visitors) of real death and disaster sites" 8

While, Tarlow (2005) defined Dark Tourism as: "visitation to places where tragedies or historically noteworthy death has occurred and that continue to impact our lives". 9

There are many reasons for visiting dark tourism sites. Dann (1998) suggested eight explanations for dark tourism.

Fear of phantoms: Where the fear of ghosts is associated with the child inside each one of us, it's the pleasure of fear of ghosts, demons and other characters and the good feeling we have when we face our fears.

Chasing change:This is related to the desire to experience everything new and to renew in the daily routine.

Yearning for Yesteryear:This is related to the feeling of nostalgia as the daily concerns and the uncertainty in the future make people "seek consolation in the past". ${ }^{10}$

Nurture of nastiness:This is related to the desire to revenge, punish persons who committed badacts and confront oppressors with their injustice.

${ }^{8}$ NeilRobinson,"Dark tourism motivations: An investigation into the motivations of visitors to sites associated with dark tourism" (Phddiss., University of Salford, 2015), 8.

${ }^{9}$ Peter Tarlow, "Dark tourism: the appealing 'dark' side of tourism and more" in: Novelli, Marina (ed.) Niche TourismContemporary Issues, Trends and Cases, 47-58, Oxford: Elsevier. (Dec 2005): 48.

${ }^{10}$ Graham M. S.Dann, The dark side of tourism. Aix-en-Provence: (International Center for Research and Studies in Tourism, 1998), 28. https://www.scribd.com/doc/92606403/1998-the-Dark-Side-ofTourism-G-Dann 
Juggling Justice: Justice deals with people who have sympathy for those who are likely to lose, whether they are criminals or not.

Present progress: This is related to tourists who visit places that make them appreciate their current standard of living. As Dann notes, by visiting the places where atrocities took place, people feel grateful that these events did not happen to them.

Dicing with Death: This is related to people who travel to distant and dangerous places in order to meditate on death.

The last thing Postmodern Promotion, this linkstravel to dark tourismsites with "the coverage received from the global media, such as television, movies, novels, songs and the Internet". 11

While Ashworth (2004) thinks that the reasons for the demand for dark tourism, which he calls "atrocity tourism" to four main reasons or arguments: The argument of curiosity, which means the desire to experience what is rare and beingcurious about uncommon things, the argument ofidentity, which is related to self-understanding and selfidentity (such as family history, spirituality or pilgrimage), the argument of horror, which is related to the attraction to allterrible and terrifying things andfinally, the argument of sympathy, where people sympathize with the victims buried in cemeteries. Ashworth also thinks that "atrocity tourism" is

${ }^{11}$ Dann, The dark, 34.

بسمة سليم

(The Egyptian Cemeteries as a Tourist Destination) 
a more specific aspect of dark tourism and the culture of tourism. $^{12}$

Pécsek (2015)studied the visitors' opinion about the National Cemetery in Budapest, which goes back to the year 1847 andspreads over fifty-six hectares and contains 3,000 gravestones and tombs, where Hungarian figures such as Lajos Kossuth, Ferenc Deák and Lajos Batthyánywere buried there. As Pécsek notes, the main reasons for these visits were the desire to escape from the stressful and noisy life of city and the desire to enjoy nature and expand the cultural and historical knowledge. While visitors are in the cemetery, they participated in many activities such as walking, visiting the funerary museum (in the cemetery), visiting famous tombs, taking photographs, and conducting research. As Pécsek indicates, none of the visitors spoke about the "dark nature". "Tombs have created additional value which has cultural nature and not related to death or suffering, "Pécsek pointed out. $^{13}$

${ }^{12}$ G.J.Ashworth,"Tourism and the heritage of atrocity: managing the heritage of South African". EPRINTS-BOOK-TITLE s.n. (2004): 2, https://www.rug.nl/research/portal/files/2977322/tourism.pdf

${ }^{13}$ Brigitta Pécsek, "City Cemeteries as Cultural Attractions: Towards an Understanding of Foreign Visitors' Attitude at the National Graveyard in Budapest,"The Central European Journal of Regional Development and Tourismvol. 7 Issue 1 (2015): 45 

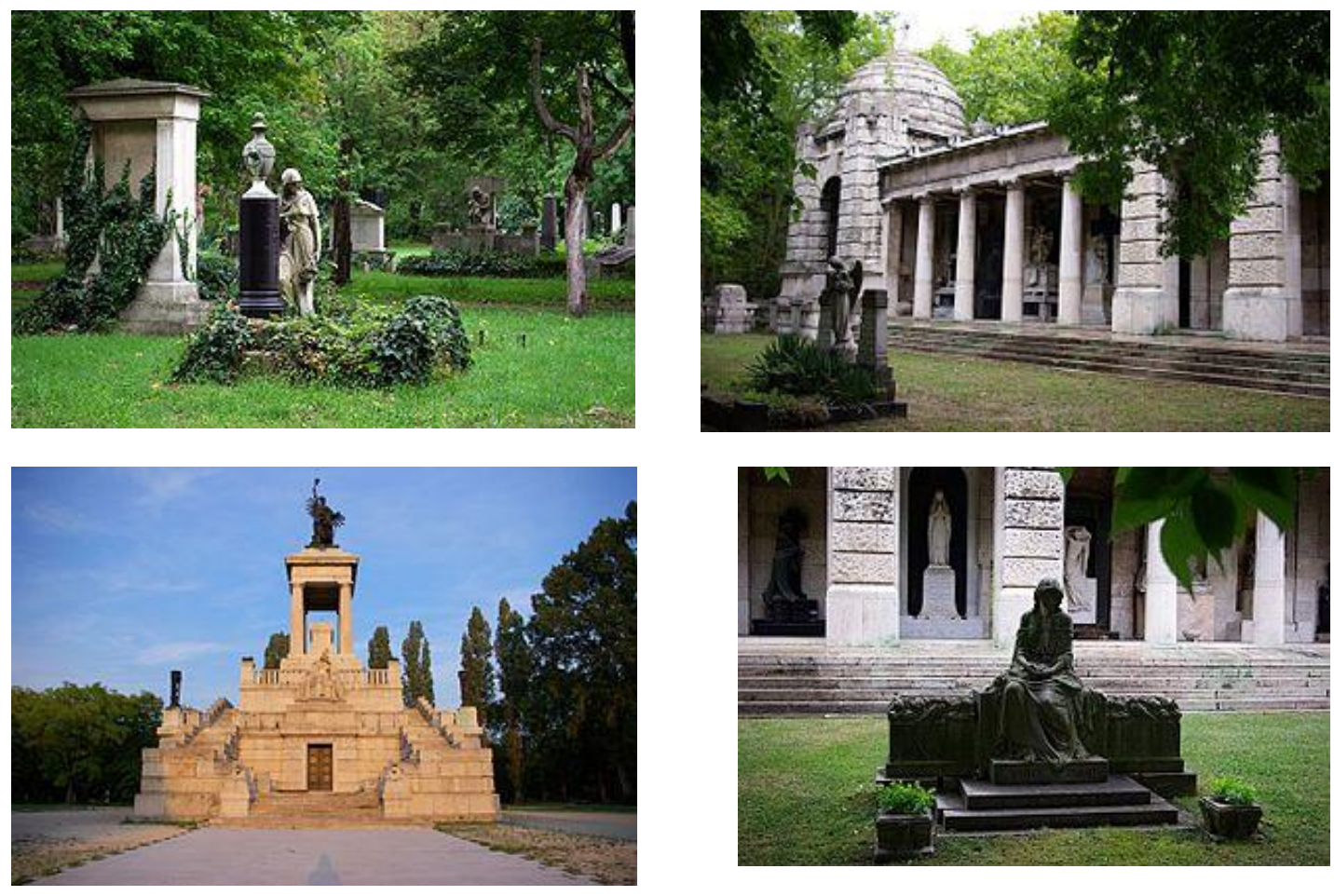

It is a cultural heritage and historical document.It provides information about the history of the place, the history of those who lived there, their origins, their works and their past lives.It is a source of historical information.

Cemetery is considered a heritage resource that can be studied in many fields, because it is more than a place where communities bury the deceased. The cemetery can be considered a social and cultural resource as it provides an insight into the characteristics of a community of people, a material cultural resource as it is an architectural and technical structure, a historical resource as it is a certificate of the past, and a tourist resource as it can be visited and provide education, entertainment and aesthetic value. In

بسمة سليم (The Egyptian Cemeteries as a Tourist Destination) 
addition, it is often used as a pilgrimage site, as visiting the dead is also considered a religious component in most cases. $^{14}$

It can also be included under the ethnic tourism such as war cemeteries especially for the victims of the Nazi fragmentation policy.Evangelical cemeteries are also important places for ethnic tourists in Poland,because of the mass exodus after World War II. The Jewish cemeteries are also important because of the extermination of the Jewish population during the war. ${ }^{15}$

(Tanas, 2004) mentions the cemetery of Beskid Niski City as an example of the cemeteries of the World War I as a tourist attraction, which was built between the years 1915 and 1918 as an expression of gratitude by the Austro-Hungarian monarchy to the dead soldiers for their courage, dedication and death and to remind future generations of the "tragedy of nations" and the death of thousands. ${ }^{16}$

From the above, we can distinguish a number of cemeteries tourism patterns in addition to the motives of tourists to visit those sites. It is worth mentioning that Egypt is full of a large number of types of cemeteries that constitute potential tourist attractions, which have many types and attract different types of tourists for example, and as a complement to what has been presented in the previous paragraph about the World War I (the cemetery of Beskid Niski), the first and second

${ }^{14}$ Tanas, "The Cemetery." 84-85.

${ }^{15}$ Tanas, "The Cemetery." 84.

${ }^{16}$ Tanas, "The Cemetery." 86. 
world wars left behind the cemeteries of soldiers from the Commonwealth countries spread in the governorates of Egypt in about 16 governorates distributed between Cairo, Alexandria, Marsa Matrouh, Alamein, Saloum, Ismailia, Suez, Port Said, and Aswan that includes mortal remains of soldiers of different nationalities and religions. Some of these Egyptian places were an eyewitness to that war and its battles. Commonwealth cemeteries are designed in the English style, which is characterized by greenness, harmonious roses, and charming nature.The cemeteries are arranged in a systematic manner and their marble panelshold the name of the dead person, his religion, his country, his military rank, and the year in which he was born. These cemeteries are a piece of art that makes you feel like you've traveled to the English countryside. Thecemeteriesare quiet and give the visitor the recreation they need as well. Why not make these cemeteries a tourist attraction for Europe countries? Since their warrior ancestors are here in Egypt and that matterthat addresses a humanitarian part of them and they have the right to boast of their ancestors who became victims of these wars. All these revive tourism and generate a national source of income for the country. ${ }^{17}$

Cemetery tourism also takes a religious dimension in Egypt. In the new valley, we find the ancient cemeteries that were and still - a witness to the beginning of the Christian era in

${ }^{17}$ Sahar Abdelfattah, "Away From Therapeutic, Recreational, Archaeological and Religious Tourism, What About Cemeteries Tourism in Egypt?" Sabaa Ayam, May 13, 2017, https://www.7-ayam.com 
which the Copts fled with their religion because of the fear of the Roman persecution of Christianity and decided to settle in the desert of the valley away from the hands of the Roman emperors and their oppression. Now, the "El Bagawat" and its streets and structures looks like a deserted city, with 263 structures, most of which are embellished from the outside, and its domes are decorated with different parts of the Torah and the Bible. In addition to the Christian drawings that are characterized by its bright colors and painted according to the "Frisco" style.One of the most important monuments of the El Bagawat is the "Shrine of Peace", it is named like that because of the presence of the peace symbol, photographed on the dome of the shrine, which is considered one of the most famous places between the students of art. There is also the "Exodus Shrine", where there are images depicting the story of the Israelites' exodus out of Egypt and how Pharaoh and his soldiers followed them. Itscolorful images also describe some stories quoted from the Old Testament, such as the story of the Prophet Noah, the story of the redemption of the Prophet Ismail, and many other religious stories. There are also "scribbles" on the cemetery represented in the writings and lines recorded by the visitors of the El Bagawat. This phenomenon increased on the walls of the cemeteriesdecorated with pictures and covered with "slurry", totaling 63 "scribbled", 29 of which are written in Arabic language, while the Greek scribes are 19 and theCoptic scribbles are $12 .^{18}$

${ }^{18}$ Khaled Qurish, "Ein Sa'af and Albjawat Archaeological Icons Tell Stories of the Bible in the Desert of the New Valley," Bawabat 
Other tombs are also found for other religious communities, including Armenian Orthodox tombs in Marina in ancient Egypt. The cemeteries of the British Protestants in Ancient Egypt, the tombs of St. Barbara in Ancient Egypt, the Latin tombs on the Salkhana Street, the cemeteries of the Roman Catholic Patriarchate in front of the Coptic Museum. ${ }^{19}$

The shrine of Al-Bayt is considered to be a prestigious place in the hearts of many Muslims. In this sense, it was chosen as a prominent tourist attraction. Each shrine has its importance. Therefore, the number of visitors to the tourist area depends on the shrine, for example, the shrine of Abu Hassan alShazli in the desert of Ayyab in the heart of the Eastern Desert. $^{20}$

In Cairo, the Calipharegion occupies about two-thirds of the number of Al-Bayt mausoleums, because of its adjacent to the oldest cemeteries of Al-Qaher, which were adjacent to many of the houses of the righteous and with quite a few AlBayt. A lot of visitors came to visit al albeit cemeteries, so they can feel the blessing and for the sake of knowledge and culture, while foreigners come from the countries of the Levant, South Asia, Yemen and Sudan, usually in organized tourism groups.In Egypt, it is customary for people to visit the shrines of al-Bayt and the righteous in the religious

Alahram, Aug 18, 2017, http://gate.ahram.org.eg/News/1566502.aspx ${ }^{19}$ Abdel Rahman Zaki, Encyclopedia of the City of Cairo in a thousand years,(Cairo: Library of the -Egyptian, 1987, pp. 198-99,) 281.

${ }^{20}$ Abdelazim Ahmed, "Al-Bayt Tombs in Cairo, Geographical Study," Annual Conference of the Department of Geography and Geographic Information Systems, Arab tourism in a changing world (July 2010): 324. 
seasons and festivals and to commemorate the people of these shrines, the number of which is more than a thousand visitors, they conduct many festive forms, known as al Mouled. ${ }^{21}$

The Jews cemeteries take a religious scent, where the Jews migrated to Egypt since the reign of Muhammad Ali Pasha, and Khedive Ismail allowed them later to establish a Jewish community in Egypt in Alexandria and Cairo, and allowed them to build their own graves and bury their dead people according to Jewish law. The Jews were interested in setting up their cemeteries in the oldest neighborhoods of Alexandria and Old Cairo. They built it on the latest Jewish architectural style in the old age in large areas. The cemeteries of the Jews located in Khartoum Square are considered as the largest cemeteries of the Jews. It's a 7 acres, containing 20 thousand cemeteries, and the last one was buried in 1956. Followed by the cemeteries of the Jews in Shatby, the area of Alshallal and "the cemeteries of the Jews" in Albassatien, which is the second largest Jewish cemetery after the graves of "Mount of Olives" in Jerusalem Cemeteries. The remains of a large number of Jews who died In Egypt before the decision of their mass emigration from Egypt during the revolution of 23 June 1952, and the small number of them left after June.

The Jews cemeteries in Alexandria and Cairo contain famous names that influenced Egyptian economic life, including the great economist Youssef Aslan Qatawi Pasha and the Egyptian leftist politician Shehat aHaroun. The cemeteries of

${ }^{21}$ Ahmed, "Al-Bayt," 325. 
the Jews in Alexandria received great attention from the Jewish community living there, and they renewed and repainted it in a semi-periodic manner to rise to the level of 5 stars due to the important people who visit from time to time. Unfortunately, Albasateen cemeteries in Cairo do not receive the same attention from the Jewish community in Cairo, because no one goes to visit them, although they include the grave of, "Musiri" family; one of the most important Jewish traces in Egypt, as it contains a high artistic value. The Supreme Council of Antiquities has restored it, in addition to being the only monarch registered within the Jewish monuments in Egypt, but the lack of interest of the Jewish community in the restoration of the graves of Albasateen made it a "ruin". 22

For researchers who interested in history and the distinguished archaeological sites, both architecturally and artistically, in Egypt, there are many archaeological mausoleumsof important personalities, the history of Egypt has been woven over time, and it has specialized itself in a very beautiful cemetery for lovers of antiquities, arts and history. A building was built-in Pharaonic style in Almounera, downtown, next to the House of the Nation. Saad Zaghloul was buried there. This building looks like a great architecture to the viewer at first sight it is a high Pharaonic temple, which gives it grandeur and surrounded by the garden from the four sides and surrounded by a wall of

${ }^{22}$ Amal Ghareeb, "Tombs of the Jews between the ruins and the other five stars," Alfajr, March 24, 2015. https://www.elfagr.com/1688174 
iron occupied with copper bands representing the lotus flower. $^{23}$

In addition, there are a number of historical cemeteries in Cairo, which have been constructed over the centuries. There are such prestigious architectural collections of ancient religious cemeteries and complexes, as well as the historical cemeteries of famous Egyptians. The cemeteries are like a public record or a living witness to the history of families and Egyptian families buried there. Their characters and their death dates were recorded on tombstones. ${ }^{24}$

The cemetery of the Mamluk is distinguished with distinctive domes such as Qansouh Boussaid dome, Qirqmas and the Seven Daughter in the Mamluk desert. That's in addition to the cemeteries of the Alawya family such as the dome of Chewakar, the first wife of King Fuad in Mamluks cemeteries, which is distinguished by its marble structure, which is carved from marble in the form of a bed identical to the Princess real bed, which not the only artistic element in the cemetery but the cemetery itself is a piece of art; its walls are covered with Marble cladding and has a magnificent dome. $^{25}$

A few meters away from the dome of the Chewakar at the same location in the Mamluk Desert, we find the dome of

${ }^{23}$ "The Shrine of Saad Pasha Zaghloul," Egypt Center for Cultural and Educational Relations, accessed March 16, 2019, http://www.misirkultur.net/ar/main.php?id_subject=146\&id_subject_ca $\mathrm{t}=2$

${ }^{24}$ Mohamed Mandur, The symphony of humans and stone (Battana Press, 2017), 128, https://books.google.com.eg/books?uid.

${ }^{25}$ Direct observation by the author, 2019. 
Afandina or the cemetery of Khedive Tawfiq, which was built by his mother, Amina Hanem, to be a burial place for the family. He was buried by the other Khedive Abbas Helmi II and Prince Mohammed Ali. The tomb is a unique masterpiece, the second most beautiful burial place in the world after the Taj Mahal is characterized by its beautiful gilded dome and its structures, which are excellent examples of marble sculpture. The mausoleum contains many antiques, rugs and candlesticks, and a set of arabesques, celebrating the opening of Suez Canal inauguration ${ }^{26}$

In fact, in the same vein regarding the Mamluki desert which is also called the Mamluk cemetery or Al-Qarafa. This area is characterized by its importance and unique urban family. It is the city of the dead, which is imitated by the travelers and drawn by orientalists. Its land embraces the remains of millions who lived and were buried by the people of Cairo throughout the ages. It is located in the northeast of Cairo under Mokattam Mountain. It is one of the most important ancient historical cemeteries. The kings and princes of Egypt used it since the end of the fourteenth century $\mathrm{AD}$ in the establishment of mosques and punks. At the end of the fifteenth century AD, architecture of the Mamluk Period. ${ }^{27}$

Despite the loss of much of this area, the rest is an architectural treasure that did not exist in any other area. It is full of monuments with domes and beacons, and there are a few domes with its inscriptions, which capture the visitor

${ }^{26}$ Direct observation by the author, 2019.

${ }^{27}$ Amal al-Alfi, Islamic Cairo - Monuments of the Mamluk Desert, (Press of the Egyptian Archaeological Registration Center),2. 
eyes, where visitors get astonished and became eager to know more and ask about its history. ${ }^{28}$
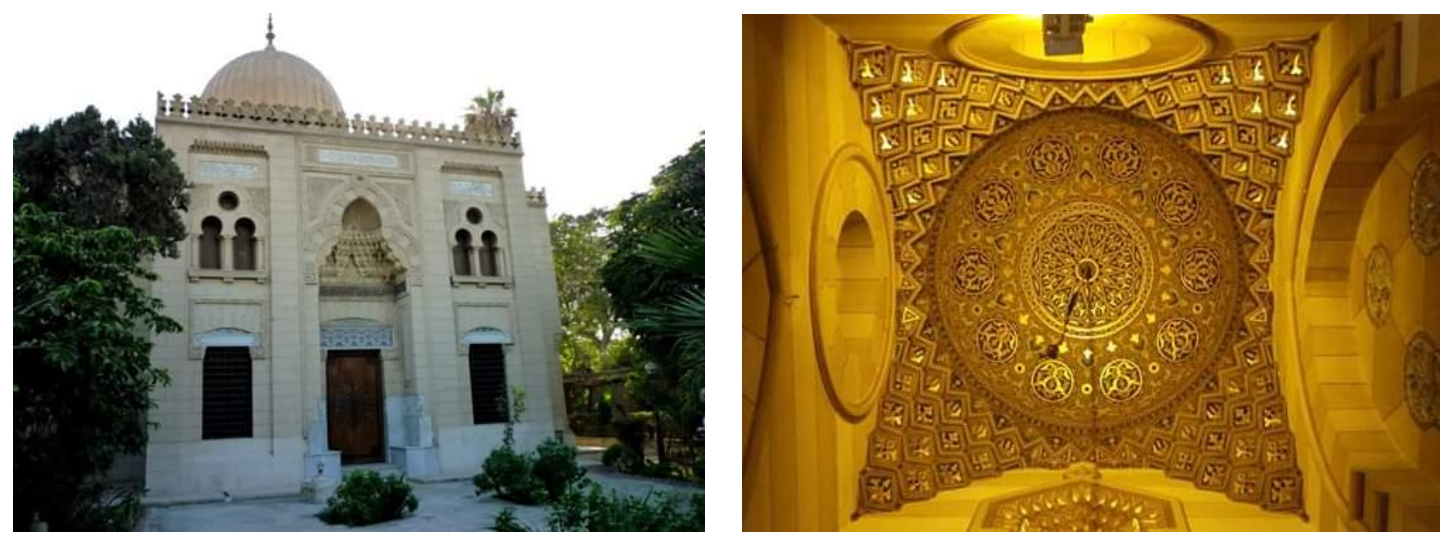

Afandina dome at Mamluk Desert, Source: author, 2019

It is now part of historic Cairo, one of the world heritage sites in Egypt since 1979. It is supervised by the East Cairo Antiquities Department of the Islamic and Coptic Archeology Department at the Ministry of Antiquities.

A tour inside these cemeteries begins with an overview from the top of Mokattam Mountain, where the tombs of Cairo appear, a quiet, silent, gloomy city inhabited by the dead. But this city is completely different from the inside, perhaps it changes because of those who buried there. ${ }^{29}$

Although historically Egyptians constructed their cemeteries on the outskirts of Cairo in the desert barren, yesterday's borders are in the heart of the city, which filled with crowds

${ }^{28}$ Hassan Abdulwahab,"Khanqat Faraj bin Barqouq, and its aria,"Studies in Islamic Archeology, Arab League Educational, Cultural and Scientific Organization (1979): 212.

${ }^{29}$ Mandur, "The symphony,", 128.

(The Egyptian Cemeteries as a Tourist Destination) 
and means of life. Where many were forced to live near the dead and others thought that the living is more important than the dead in everything, even in cemeteries.

This has been supported by many factors such as the ecological relationship between cemeteries and the Islamic capitals of Egypt. The development of cemeteries has accompanied the urban development of these capitals. It has become an integral part of it. The houses have become parts of graves, where many people are living in homes that have cemeteries within it. this also leads to an increase the number of holy martyrs and righteous people shrines. ${ }^{30}$

There are two characteristics of the Cairo Cemeteries; there found built-up spaces and provided with all the means of living. there are some people inhabitant those spaces on a permanent basis, while some are living in buildings located in the vicinity of Imam Shafi'i, Barqouq, and Qaitbay cemeteries. $^{31}$

Moreover, he noticed the existence of a clear defect in the infrastructure in the Mamluk cemetery area, which calls for urgent intervention to protect and preserve it. The abovementioned defects affect (toilets, slums, electricity, water, sanitation, floors, buildings, shops). The sluggish cultural and educational level for all people living in those cemeteries and tombs, which is reflected in the surrounding environment of random buildings and they neglected the monuments so they become dumps of garbage and waste.

\footnotetext{
${ }^{30}$ Mandur, "The symphony,", 128.

${ }^{31}$ RashaHosny, "Cairo's ancient tombs are alive" Alahram, Aug 31, 2015, http://www.ahram.org.eg/News/121649/3/428544/
} 
This requires the establishment of integrated community awareness and participation program to develop people who live in Mamluk cemetery on cultural, educational, social, and economic levels. ${ }^{32}$

In the light of such phenomena and their impact on the effects of the region and the possibility of converting it into a potential tourist attraction.The author interviewed some decision-makers and stakeholders in the region, where Mohamed Abdullah, director general of the East Cairo area, who is responsible for managing monuments of Mamluk cemetery, he sees that people living in cemetery pose a grave danger to the area because of the encroachment they commit due to lack of awareness of the importance of the monuments.

The region suffers from local problems related to hygiene and paving the streets and all these factors weaken the region as a tourist destination, although at the archaeological level conscious area of history and monuments it is possible to make it an open museum, such as the Almoez Street. He added. In order to reach that result, we must first spread archaeological and cultural awareness among the members of the community and solve the problems of encroachments with the localities and paving streets and cleaning the garbage and restore of the effects of the unrestored monuments. $^{33}$

Mohammed Badawi, a tourist guide, agrees with him and confirms that the area was already on the tourism map until

${ }^{32}$ Direct observation by the author, 2019.

${ }^{33}$ Mohamed Abdullah, face to face Interview, March 21, 2019. 
2009 and was stopped by the local community as a threat to tourists. "The region is a hotbed of drugs, harassment, begging and theft," he says.

While it was listed before 2009 but also did not take great importance in the programs prepared by the tourism companies. Moreover, the place should be reclassified to solve problems to turn it into an open museum of monuments and cemeteries tourism. Adding that Egypt boasts a good number of religious cemeteries, which is a destination for $\mathrm{Al}$ al-Bayt (The prophet family) from the countries that received them at the time of the great sedition. Such as the North African countries, Azerbaijan and others, and then hosted by Egypt and they died here in Egypt. Their cemeteries turned into shrines which visited by the Egyptians alongside with the tourists from different countries. Bhnasa city is an example, which is considered as the second Baqiea. Unfortunately, no shrines are given sufficient attention, they are not safe, their roads are not paved, and there is a problem of accessibility. ${ }^{34}$

In this context, Mohamed Abdel Aziz, the director of Cairo's historical department at the Ministry of Antiquities, said that historical Cairo is registered in UNESCO as a living city. That registration is not only because of the old buildings but also because it is a historic city with a historical atmosphere, that reflected in daily life activities that are rooted in the past. These activities are customs, traditions and rites associated with beliefs, which constitute an intangible heritage practiced by Egyptians on a daily basis in the streets of Cairo and its

${ }^{34}$ Mohammed Badawi, face to face Interview, March 25, 219.

بسمة سليم

(The Egyptian Cemeteries as a Tourist Destination) 
squares. Especially, the spiritual places in the cisterns, where the blessing stems not only from the famous shrines but also from all Muslim graves from Islamic history.

All of the above leads us to a very important point. If we really want to protect our archaeological heritage to reach to future generations, we must first care about the people living in its surrounding urban environment. It is inconceivable that we care about statues without taking care of human beings. Human beings are the makers of influence and civilizations. It is not logical to rebuild the antiquities ask the surrounding population to keep it from encroachments or thefts without rehabilitating their urban environment and upgrade their social, economic and cultural level.

The extent of the concern we pay for them, their living, their housing and the services provided to them will contribute to protecting and preserving our monuments in cooperation between the people and the government.

It was the core reason behind the project proposal to revive Mamluk cemetery on both urban and construction level.

The project aims at reviving the Mamluk cemetery area, while preserving the architectural and sensational character of the area. And also through raising the cultural and social level of the people of the region and linking them to the officials of the Antiquities through the launching of service projects in cooperation with the concerned governmental state agencies. In addition to place the area of the Mamluk cemetery on the map of the international attractions as a tour 
destination in Cairo city, which is recorded on the list of world heritage in $1979 .^{35}$

The European Union Commission takes over the cost of implementing the two projects. The Office of Arcanius Engineering carries out the project, while the Ministry fully supervising the implementation steps through the Cairo Historic Development Project.

The project combines the conservation of architectural and historical heritage by attracting attention to Cairo monuments, as well as promoting the traditional crafts of the region, including glass blowing, metal or wood decoration, hand-woven and other hand-woven carpets.

"I noticed the nature of the historical region and its cultural depth, which tells the details of the history of Egypt and the lives of the Egyptians, so I decided to use it whatever the obstacles," said Agnishka, Arkaneous office manager. She is about to establish a touristic attraction in this area, which is back to the days of Sultan Qaitbay, she added.

During the supervision of several Western institutions and the European Union and under the supervision of the Egyptian Ministry of Antiquities that decided to convert the area to a tourist destination. This has revealed details, and offered residents handicrafts and craft that excite tourists, with concerts and art workshops, where Arab and foreign tourists participate in. In no time, the inhabitants reacted positively with this project. That is because, on the one hand, it provides a safe place for their children, where they can have fun and grow their talents free of charge. On the other

${ }^{35}$ Mohamed Abdel Aziz, face to face Interview, March 21, 2019. 
hand, they were able to strengthen the case of bonding with the people of the region who have covered their photos on several occasions and placed on the walls of the center in a permanent exhibition. $^{36}$

We conclude that from the statement of Mohammed Abdullah, the Director General of East Cairo that despite the project success and the state of embarking, the area is very large and the number of monuments recorded is more than 60 monuments. The interest in one monument without the rest does not work to solve the problems of the region, but is a good gesture, preferably circulated on the rest of the region to reach quick and tangible results. ${ }^{37}$

36AgnishkaDobrowolski, face to face interview, Dec 16, 2018.

37Mohamed Abdullah, face to face Interview, March 21, 2019. 


\section{Conclusion:}

- The diversity of tourism in Egypt is not limited to tourism companies that offer fixed and rigid tourism packages that are limited to classical tourism in Egypt such as the Pyramids, the Egyptian Museum, El Moez Street, Al Qalaa, Luxor and Aswan.

- Egypt has a large number of cemeteries of unique historic, religious and architectural value, but are not exploited by tourism and are not included on the tourism map, although many countries pay great attention to it as a source of income.

- Although there are some signs of hope to revive the cemeteries, it is weak, as the tourism of the graves need an integrated plan to introduce and highlight them, in addition to solving their related problems. 


\title{
Biblioraphy
}

Abdel RahmanZaki, Encyclopedia of the City of Cairo in a thousand years, Cairo: Library of the Anglo-Egyptian, 1987, pp. 198-99, 281.

\begin{abstract}
Abdelfattah, Sahar. "Away from therapeutic, recreational, archaeological and religious tourism."What about cemeteries tourism in Egypt?" SabaaAyam, May 13, 2017, https://www.7-ayam.com
\end{abstract}

Abdulwahab,Hassan. "KhanqatFaraj bin Barqouq, and its aria." Studies in Islamic Archeology,Arab League Educational, Cultural and Scientific Organization (1979): 212.

Ahmed, Abdelazim. "Al-Bayt Tombs in Cairo, Geographical Study. "Annual Conference of the Department of Geography and Geographic Information Systems, Arab tourism in a changing world(July 2010): 324-325
Al-Alfi, Amal.Islamic Cairo - Monuments of the Mamluk
Desert.Press of the Egyptian Archaeological Registration Center.

Ashworth, G. J. "Tourism and the heritage of atrocity: managing the heritage of South African", EPRINTS-BOOK- 


\section{TITLE s.n. (2004).}

https://www.rug.nl/research/portal/files/2977322/tourism.pdf

Dann, Graham M. S. 1998. The dark side of tourism. Aix-enProvence: International Center for Research and Studies in Tourism. https://www.scribd.com/doc/92606403/1998-theDark-Side-of-Tourism-G-Dann

Egypt Center for Cultural and Educational Relations."The Shrine of Saad Pasha Zaghloul," accessed March 16, 2019. http://www.misirkultur.net/ar/main.php?id_subject=146\&id $\underline{\text { subject_cat }=2}$

Ghareeb,Amal. "Tombs of the Jews Between the Ruins and the Other Five Stars." Alfajr, March 24, 2015.

https://www.elfagr.com/1688174 http://www.deturope.eu/img/upload/content_42123976.pdf

Mandur, Mohamed. The Symphony of Humans and

Stone.Battana Press, 2017, https://books.google.com.eg/books?uid.

Pécsek, Brigitta. "City Cemeteries as Cultural Attractions: Towards an Understanding of Foreign Visitors'Attitude at the National Graveyard in Budapest." The Central European Journal of Regional Development and Tourism vol. 7 Issue 1 (2015): 44-61.

Qurish, Khaled. "EinSa'af and Albjawat Archaeological Icons Tell Stories of the Bible in the Desert of the New 
Valley." BawabatAlahram, Aug 18, 2017, http://gate.ahram.org.eg/News/1566502.aspx

Robinson, Neil. "Dark tourism motivations: An investigation into the motivations of visitors to sites associated with dark tourism" Phd diss., University of Salford, 2015.

Rojek, C., and John Urry, Touring Cultures: Transformations of Travel and Theory. New York Taylor \&Francise-Library ,2003.

http://www.academia.edu/823938/Touring_Cultures_by_Urr y_and_Rojek_book_

Seaton, A.V., "Guided by the dark: From thanatopsis to thanatourism." International Journal of Heritage Studies, 2 (4) (1996): 234-244.

Tanas, slawoj."The Cemetery as a Part of the Geography of Tourism".University of Lodz, 2004.

Tarlow, Peter. "Dark tourism: the appealing 'dark' side of tourism and more" in: Novelli, Marina (ed.) Niche Tourism Contemporary Issues, Trends and Cases, 47-58, Oxford: Elsevier. (Dec 2005). 